Katarzyna T. Boratýnska

Uniwersytet w Biatymstoku

\title{
ZAGROŻENIE SUROWA KARA JAKO SAMODZIELNA PODSTAWA STOSOWANIA TYMCZASOWEGO ARESZTOWANIA W ŚWIETLE ORZECZNICTWA EUROPEJSKIEGO TRYBUNAŁU PRAW CZŁOWIEKA
}

Tymczasowe aresztowanie jako środek, który w najbardziej dotkliwy sposób wkracza w prawnie chronioną sferę wolności osobistej człowieka jest przedmiotem nie tylko regulacji krajowych, ale także międzynarodowych, w szczególności Powszechnej Deklaracji Praw Człowieka, Międzynarodowego Paktu Praw Politycznych i Obywatelskich ${ }^{1}$ oraz Europejskiej Konwencji o Ochronie Praw Człowieka i Podstawowych Wolności² (dalej EKPC).

Kwestię prawidłowości stosowania tymczasowego aresztowania obrazuje najbardziej orzecznictwo Europejskiego Trybunału Praw Człowieka (dalej ETPC), który sądzi je poprzez pryzmat standardów konwencyjnych.

Zgodnie z art. 5 ust. 1 lit. c Konwencji o Ochronie Praw Człowieka i Podstawowych Wolności tymczasowe aresztowanie stosuje się celem ,postawienia przed właściwym organem, jeżeli istnieje uzasadnione podejrzenie popełnienia czynu zagrożonego karą lub, jeśli jest to konieczne, w celu zapobieżenia popełnieniu takiego czynu, lub uniemożliwienia ucieczki po jego dokonaniu."

$\mathrm{Na}$ tym tle jawi się zagadnienie zagrożenia surową karą (art. 258 § 2 k.p.k.) jako samodzielna przesłanka stosowania tymczasowego aresztowania. Istotne również z tego względu, że powyższy przepis nie przewiduje stosowania tymczasowego aresztowania na tej podstawie, że oskarżonemu zarzucono czyn zagrożony surową karą.

Problematyka zagrożenia surową karą jako samodzielna podstawa zastosowania tymczasowego aresztowania od lat wzbudza wiele kontrowersji. W orzecznictwie ścierają się dwa przeciwstawne stanowiska w zakresie nadania samodzielności

$1 \quad$ Międzynarodowy Pakt Praw Obywatelskich i Politycznych otwarty do podpisu w Nowym Jorku dnia 19 grudnia 1966 r. Dz.U. z 1977 r. Nr 38, poz. 167 zał.

2 Konwencja o Ochronie Praw Człowieka i Podstawowych Wolności sporządzona w Rzymie dnia 4 listopada 1950 r., zmieniona następnie Protokołami nr 3, 5 i 8 oraz uzupełniona Protokołem nr 2, Dz.U. z 1993 r. Nr 61, poz. 284 ze zm. 
podstawie stosowania tymczasowego aresztowania $\mathrm{z}$ art. $258 \S 2$ k.p.k. Z jednej strony mamy do czynienia z judykatami stanowiącymi o tym, że ,potrzeba zastosowania tymczasowego aresztowania w celu zabezpieczenia prawidłowego toku postępowania może być uzasadniona grożącą oskarżonemu surową karą, która jest samodzielną, szczególną podstawą stosowania środków zapobiegawczych, gdy oskarżonemu zarzuca się popełnienie zbrodni lub występku zagrożonego karą pozbawienia wolności, której górna granica wynosi co najmniej 8 lat, a więc ustawowe zagrożenie karą będzie podstawą stosowania tymczasowego aresztowania jeszcze przed wydaniem wyroku, jak również w sytuacji, gdy sąd I instancji skazał oskarżonego na karę pozbawienia wolności nie niższą niż 3 lata"3. W tym przypadku o zastosowaniu tymczasowego aresztowania decyduje konkretny wymiar kary pobawienia wolności ${ }^{4}$.

Z drugiej zaś stwierdzenie, że „Błędne jest przekonanie, jakoby sam zarzut popełnienia zbrodni lub występku zagrożonego w sankcji przepisu, typizującego czyn zabroniony, karą pozbawienia wolności, której górna granica nie jest niższa od lat 8 stanowił samodzielną podstawę stosowania środka zapobiegawczego. W istocie rzeczy przepis art. $258 \S 2$ k.p.k. nie ustanawia żadnej odrębnej i samodzielnej podstawy stosowania tymczasowego aresztowania. W treści tego przepisu ustawodawca zawarł bowiem jedynie uprawnienie adresowane do sądu stosującego tymczasowe aresztowanie ograniczenia uzasadnienia potrzeby stosowania tymczasowego aresztowania w celu zabezpieczenia prawidłowego toku postępowania - w wypadkach, gdy oskarżonemu zarzucono popełnienie zbrodni, występku zagrożonego karą pozbawienia wolności, której górna granica wynosi co najmniej 8 lat pozbawienia wolności, lub też, gdy oskarżony został skazany na karę pozbawienia wolności nie niższą od 3 lat - grożącą temu oskarżonemu, w związku z do tej pory ujawnionymi okolicznościami przedmiotowymi i podmiotowymi, surową karą5".

W literaturze przedmiotu podkreśla się, że przesłanki określone w art. 258 $\S 2$ k.p.k. nie mogą być traktowane jako samodzielne w tym znaczeniu, że stwarzają jedynie domniemanie utrudniania przez oskarżonego postępowania karnego. Podstawę zastosowania tymczasowego aresztowania musi stanowić zawsze cel procesowy, tj. zabezpieczenie prawidłowego toku postępowania, co powinno być wykazane w uzasadnieniu stosownego postanowienia ${ }^{6}$.

Zob. post. SN z 26.4.2006 r., WZ 14/06, OSNwSK 2006, Nr 1, poz. 912, post. SA w Katowicach z 14 grudnia 2005 r., sygn. akt II AKz 748/05, Lex nr 164607, post. SA w Szczecinie z 29 grudnia 2005 r., sygn. akt II AKz 341/05, OSA 2006, Nr 10, poz. 58.

4 Nie można skutecznie powoływać się na przesłankę z § 2, czyli obawę zakłócenia prawidłowego toku postępowania, wynikłą z surowości kary ze względu na fakt orzeczenia kar niższych niż 3 lata pozbawienia wolności oraz zapowiedź apelacji wyłącznie na korzyść oskarżonego. Zob. post. SA w Katowicach z 31.5.2000 r., II AKz 131/00, OSA 2001, Nr 2, poz. 11.

$5 \quad$ Zob. post. SA we Wrocławiu z 6.12.2006 r., III AKz 626/06, OSA 2007, Nr 3, poz. 11.

$6 \quad$ Uchw. SN z 19 stycznia 2012 r., I KZP 18/11, OSNKW 2012, Nr 1, poz. 1. 
W związku z powyższym z inicjatywy Rzecznika Praw Obywatelskich, Sąd Najwyższy w składzie 7 sędziów w dniu 19 stycznia 2012 r. podjął uchwałę ${ }^{7}$, w której uznał, że ,podstawy stosowania tymczasowego aresztowania, określone w art. 258 $\S 2$ k.p.k., przy spełnieniu przesłanek wskazanych w art. $249 \S 1$ i art. $257 \S 1$ k.p.k. i przy braku przesłanek negatywnych określonych w art. 259 § 1 i 2 k.p.k., stanowią samodzielne przesłanki szczególne stosowania tego środka zapobiegawczego".

W uzasadnieniu uchwały Sąd Najwyższy stwierdził dodatkowo, że ,gdyby chcieć przyjąć, że dla zastosowania tymczasowego aresztowania na podstawie art. $258 \S 2$ k.p.k. konieczne było wykazanie istnienia uzasadnionej obawy matactwa lub uzasadnionej obawy ucieczki, ukrycia się oskarżonego, czy też innego bezprawnego utrudniania postępowania karnego (a więc podstaw stosowania tymczasowego aresztowania określonych w art. $258 \S 1$ k.p.k.), to przepis $\S 2$ okazałby się zupełnie zbędny. Taki sposób dokonywania interpretacji stałby w rażącej sprzeczności z zakazem wykładni per non est. Jeżeli więc ustawodawca przewidział w $\S 2$ art. 258 k.p.k. dodatkową podstawę stosowania tymczasowego aresztowania, a jednocześnie z żadnego przepisu nie wynika konieczność łącznego wystąpienia przesłanek określonych w $\S 1$ i 2 , to surowa kara grożąca oskarżonemu, w okolicznościach opisanych w $§ 2$ art. 258 k.p.k., stanowić może samodzielną przesłankę szczególną".

Cytowana uchwała nie tylko nie rozwiała dotychczasowych kontrowersji i niejednolitości poglądów, lecz wręcz przeciwnie - rozbudziła dyskusję w tym temacie ${ }^{8}$. Odniesienie do uchwały SN z 19.01.2012 r. można także znaleźć w wyroku9 Trybunału Konstytucyjnego z dnia 20 listopada 2012 r., w którym uznał on, że ,,interpretacja art. $258 \S 2$ k.p.k. przedstawiona w powołanej uchwale Sądu Najwyższego powoduje, że tymczasowe aresztowanie może być stosowane bez konieczności wykazania rzeczywistej potrzeby zabezpieczenia przebiegu toczącego się postępowania karnego, w szczególności w rozumieniu art. 258 k.p.k. W tym kontekście norma zawarta w zaskarżonym art. $263 \S 7$ k.p.k. nie spełnia testu proporcjonalności i z tego względu jest niezgodna z nakazem jednoznacznego określenia przesłanek pozbawienia wolności zawartym w art. 41 ust. 1 w zw. z art. 31 ust. 3 Konstytucji” ${ }^{10}$.

Zob. post. SN z 12 marca 2009 r., sygn. akt WZ 15/09, OSNKW 2009, nr 7, poz. 52; J. Skorupka, art. 258 nb 32 , 33, (w:) J. Skorupka, Kodeks postępowania karnego. Komentarz, Warszawa 2012, S. Waltoś, Proces karny, Warszawa 2008, s. 434-435.

8 Zob. J. Skorupka, Glosa do uchwały Sądu Najwyższego z dnia 19 stycznia 2012 r., sygn. I KZP 18/11, OSP 2012, nr 7-8, poz. 546; A. Woźniak, Glosa do uchwały Sądu Najwyższego z dnia 19 stycznia 2012 r., sygn. I KZP 18/11, OSP 2012, nr 6, poz. 66; M. Drewicz, Glosa do uchwały Sądu Najwyższego z dnia 19 stycznia 2012 r., sygn. I KZP 18/11, e-CzKNP 2012, poz. 8; D. Drajewicz, Glosa do uchwały Sądu Najwyższego z dnia 19 stycznia 2012 r., sygn. I KZP 18/11, Prok. i Pr. 2013, nr 10; Ł. Cora, Glosa do uchwały Sądu Najwyższego z dnia 19 stycznia 2012 r., sygn. I KZP 18/11; R. Rynkun-Werner, Glosa do uchwały Sądu Najwyższego z dnia 19 stycznia 2012 r., sygn. I KZP 18/11, „Palestra” 2013, nr 11-12; M. Kornak, Glosa do uchwały Sądu Najwyższego z dnia 19 stycznia 2012 r., sygn. I KZP 18/11, LEX/el 2013.

$9 \quad$ Wyr. TK $z$ dnia 20 listopada 2012 r., SK 3/12, OTK-A 2012, nr 10, poz. 123.

10 Uzasadnienie do wyr. TK z dnia 20 listopada 2012 r., SK 3/12, OTK-A 2012, nr 10, poz. 123. Stanowisko TK potwierdza także wcześniejsze orzecznictwo, zgodnie z którym, jeśli chodzi o wypadek stosowania tymczasowego aresztowania po wydaniu pierwszego wyroku skazującego przez sąd pierwszej instancji, sam fakt orzeczenia surowej kary nie uzasadnia jeszcze zastosowania tymczasowego aresztowania. Niezbędne jest wykazanie, że aresztowanie jest celowe dla zabezpieczenia prawidłowego toku postępowania. Zob. post. SN z 15.07.2003 r., 
Powyższe stwierdzenie oznacza, że pomimo tego, iż TK wydał rozstrzygnięcie w zakresie art. $263 \S 7$ k.p.k., to jednak odniósł się także do przesłanki z art. $258 \S 2$ k.p.k., poddając w wątpliwość pod kątem zgodności z Konstytucją RP domniemanie ustanowione przez ten przepis, a polegające na tym, że oskarżony w celu uniknięcia surowej kary będzie podejmował działania uniemożliwiające lub utrudniające prawidłowy bieg postępowania ${ }^{11}$.

Ma to istotne znaczenie dlatego, że art. $258 \S 2$ k.p.k. określa samoistną podstawę stosowania tymczasowego aresztowania w postaci grożącej oskarżonemu surowej kary, która stanowiła podstawę wydania niekorzystnych dla niego rozstrzygnięć, zaś domniemanie zawarte w tym przepisie nie musi znajdować potwierdzenia w ustaleniach faktycznych odnoszących się do tego, czy rzeczywiście istnieje obawa, że oskarżony będzie utrudniał bieg postępowania ${ }^{12}$.

W związku z powyższym, celem niniejszego opracowania będzie przeanalizowanie charakteru tej przesłanki poprzez pryzmat orzecznictwa ETPC oraz odpowiedź na pytanie, czy stanowisko wyrażone przez SN w wyżej cytowanej uchwale wypełnia standardy konwencyjne w zakresie prawidłowości stosowania tymczasowego aresztowania, a także jak zmiana art. 258 §2 przez ustawę z 27 września 2013 r., o zmianie ustawy kodeks postępowania karnego oraz niektórych innych ustaw $^{13}$ wpisuje się w orzecznictwo ETPC odnoszące się do zagrożenia surową karą jako samodzielnej przesłanki tymczasowego aresztowania.

Przechodząc do standardów europejskich w zakresie stosowania tymczasowego aresztowania wskazać należy, że to ETPC niejednokrotnie zaznaczał, iż podstawą stosowania tymczasowego aresztowania mogą być przede wszystkim przesłanki procesowe i przesłanka prewencyjna w postaci obawy popełnienia nowego przestęp-

sygn. akt WZ 30/03, OSNwSK 2003, nr 1, poz. 1557, post. SN z 20.08.2003 r., sygn. akt WZ 35/03, OSNwSK 2003, nr 1, poz. 1755, post. SN z 20.03.2007 r., sygn. akt WZ 8/07, OSNwSK nr 2007, nr 1, poz. 654.

11 Zob. także P. Kładoczny, Art. 258 § 2 k.p.k. jako podstawa tymczasowego aresztowania, (w:) P. Turek (red.), Przewlekłość tymczasowego aresztowania w Polsce w świetle europejskich standardów ochrony praw człowieka Warszawa 2013, s. 156.

12 W zakresie domniemań związanych z art. 258 § 2 k.p.k. zob. szerokie rozważania M. Warchoła, Domniemania przy tymczasowym aresztowaniu, (w:) Funkcje procesu karnego. Księga jubileuszowa Profesora Janusza Tylmana, T. Grzegorczyk (red.), Warszawa 2011 oraz Zagrożenie surową karą pozbawienia wolności jako szczególna przesłanka stosowania tymczasowego aresztowania (uwagi na tle wniosku Rzecznika Praw Obywatelskich do Sądu Najwyższego i uchwały z dnia 19 stycznia 2012 r., I KZP 18/11, (w:) Przewlekłość tymczasowego aresztowania w Polsce w świetle europejskich standardów ochrony praw człowieka, P. Turek (red.), Warszawa 2013, s. 128-130, gdzie Autor wskazuje, że określenie domniemanie powiązane z art. 258 par. 2 k.p.k. jest wynikiem nieszczęśliwego określenia zawartego w Uzasadnieniu rządowego projektu kodeksu postępowania karnego. Nie może to jednak mieć charakteru przesądzającego, skoro nie zostało wprost wysłowione w ustawie. W uzasadnieniu tym zaleca się jednak dużą ostrożność w sięganiu do przesłanki z art. 258 § 2 k.p.k., a ponadto przez „przyczyny zabezpieczenia prawidłowego toku postępowania” ustawodawca rozumie „sytuacje, w których zastosowanie tymczasowego aresztowania może okazać się konieczne ze względu na silne poruszenie opinii publicznej faktem popełnienia ciężkiego przestępstwa, którego charakter, sposób dokonania oraz tragiczne skutki wywołują powszechne wzburzenie i żądanie maksymalnego zabezpieczenia skuteczności wszczętego postępowania karnego. W takich warunkach pozostawanie oskarżonego na wolności może wywołać niepokoje społeczne. Por. także. A Kiełtyka, Tymczasowe aresztowanie ze względu na grożącą oskarżonemu surową karę a standardy ochrony praw człowieka, http://www.parz.pl/index.php/publikacje/51-tymczasowe-aresztowanie-ze -wzgldu-na-groc-oskaronemu-surow-kar-a-standardy-ochrony-praw-czowieka

13 Ustawa z 27 września 2013 r., o kodeks postępowania karnego oraz niektórych innych ustaw, Dz.U. z 2013 r., poz. 1247. 
stwa, przy istnieniu konkretnych dowodów. W wyroku z 4.10.2005 r. w sprawie nr 9190/03 Bacciev v. Mołdawia ETPC uznał, że „Linia orzecznicza rozwinięta na podstawie ETPC wyprowadziła cztery podstawowe przesłanki akceptujące stosowanie tymczasowego aresztowania przed wydaniem wyroku w odniesieniu do osoby podejrzanej o popełnienie czynu zagrożonego surową karą:

- ryzyko, iż oskarżony nie stawi się na rozprawę,

- ryzyko, iż oskarżony, w przypadku zwolnienia, podejmie działania zmierzające do zaburzenia sprawowania wymiaru sprawiedliwości,

- ryzyko, iż oskarżony w przypadku zwolnienia popełni nowe przestępstwo,

- ryzyko, iż oskarżony w przypadku zwolnienia będzie naruszać porządek publiczny."

ETPC, jako przyczyny naruszania przez Polskę art. 5 ust. 3 EKPC, najczęściej wskazuje powoływanie się przez polskie sądy w postanowieniach o zastosowaniu izolacyjnego środka zapobiegawczego na: racjonalne podejrzenie, że oskarżony popełnił zarzucany mu czyn (co samo w sobie nie jest wystarczającym powodem dla przedłużenia aresztowania); powagę popełnionego przestępstwa i prawdopodobieństwo surowej kary (podwyższające ryzyko niestawienia się oskarżonego w sądzie, ale niewystarczające dla przedłużenia aresztu) i prawdopodobieństwo matactwa bez zindywidualizowanego określenia, czy w danej sprawie prawdopodobieństwo jego wystąpienia jest wysokie ${ }^{14}$.

ETPC nie akceptuje w pełni zagrożenia surową karą jako istotnej, wystarczającej i możliwej do stosowania na wszystkich etapach postępowania (zwłaszcza późniejszych) podstawy tymczasowego aresztowania, gdyż ocena w tym zakresie musi być odniesiona do wielu innych czynników, które będą wskazywać na niebezpieczeństwo bezprawnego utrudniania postępowania przez oskarżonego. Przewidywany wysoki wymiar kary oraz ciężar materiału dowodowego mogą mieć znaczenie, lecz jako takie nie są decydujące w zakresie stosowania tymczasowego aresztowania $^{15}$.

Zdaniem ETPC zagrożenie surową karą może być samoistną podstawą stosowania tymczasowego aresztowania tylko na jego wstępnym etapie, ${ }^{16}$ gdyż o ile okoliczność zagrożenia surową karą może uzasadniać domniemanie, że oskarżony będzie utrudniał postępowanie karne w jego początkowej fazie, o tyle wraz z upływem czasu i postępem postępowania dowodowego, traci ona na znaczeniu ${ }^{17}$. Podstawa

14 Por. D.R. Swanson, Instytucja tymczasowego aresztowania w Polsce. Analiza i rekomendacje oparte na ogólnych zasadach prawa oraz orzecznictwie Europejskiego Trybunału Praw Człowieka, (w:) P. Wiliński, J. Izydorczyk, D.R. Swenson, D. Raczkiewicz, Ł. Lewandowski, M. Wasylczuk, M. Gilewicz, Stosowanie tymczasowego aresztowania w Polsce. Analiza i rekomendacje. Raport Fundacji Instytutu na rzecz Państwa Prawa, Lublin-Poznań-Warszawa 2008, s. 45.

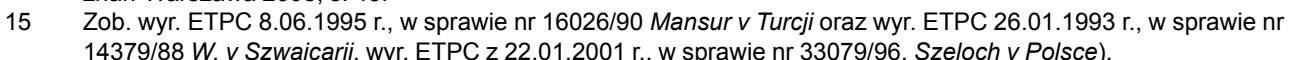

16 E. Samborski, Zarys metodyki pracy prokuratora, Warszawa 2008, s. 163.

17 Por. np. wyr. ETPC 19.5.2009 r., w sprawie nr 18353/03 Kulikowski v. Polsce. 
ta zatem nie wystarcza do uzasadnienia całego okresu tymczasowego aresztowania. Zdaniem ETPC powinny pojawić się jeszcze inne ,istotne” i ,wystarczające” podstawy do uzasadniania dalszego pozbawiania wolności oskarżonego. Co więcej, musi mieć to potwierdzenie w zebranych dowodach pochodzących najlepiej z różnych źródeł ${ }^{18}$.

ETPC akceptuje funkcjonowanie szczególnego domniemania wynikającego z prognozowanej kary i ciężaru gatunkowego zarzucanego przestępstwa, o ile wraz z upływem czasu i w świetle kolejnych czynności - prognozowany wymiar kary jest ponownie ustalany ${ }^{19}$.

Ponadto ETPC zwraca także uwagę na to, że dolegliwość grożącej kary oraz ciężar zarzutów sam w sobie nie może uzasadniać stosowania tymczasowego aresztowania w postępowaniu przygotowawczym przez długi okres ${ }^{20}$.

Analogicznie ETPC orzekł w wyroku z 23 czerwca 2005 r. w sprawie nr 44722/98 Łatasiewicz v. Polska, stwierdzając, że surowość wyroku, jaki może w przyszłości zapaść i związany z nim ciężar gatunkowy stawianych zarzutów daje organom krajowym uzasadnioną podstawę do przyjęcia ryzyka ucieczki, a nawet ponownego popełniania czynów zabronionych ${ }^{21}$. Niemniej jednak ciężar przedstawionych skarżącemu zarzutów nie może sam z siebie uzasadniać długich okresów stosowania tymczasowego aresztowania ${ }^{22}$. Wraz z upływem czasu surowość przewidywanej kary samodzielnie lub w powiązaniu $\mathrm{z}$ innymi podstawami, na które powoływały się sądy nie może być uznana za wystarczające uzasadnienie przetrzymywania oskarżonego w areszcie przez bardzo długi okres.

Zaznaczyć tu trzeba, że w dużej liczbie spraw, w których zostało stwierdzone naruszenie przez Polskę art. 5 ust. 3 EKPC, stosowanie tymczasowego aresztowania było uzasadniane właśnie grożącą oskarżonemu surową karą, czyli przesłanką wskazaną w art. $258 \S 2$ k.p.k.

ETPC stwierdził także, że niebezpieczeństwo ucieczki ze strony oskarżonego nie może być oceniane jedynie na podstawie surowości wymiaru kary, który może zostać orzeczony. Musi ono zostać ocenione przy odniesieniu się do szeregu innych istotnych czynników, które mogą albo potwierdzić istnienie niebezpieczeństwa ucieczki, albo wykazać, iż niebezpieczeństwo to jest tak małe, że nie może uzasadnić stosowania aresztowania w trakcie procesu. Ryzyko ucieczki winno zostać ocenione w świetle czynników związanych z charakterem danej osoby, jej moralnością, miejscem zamieszkania, zawodem, majątkiem, związkami rodzinnymi oraz róż-

\footnotetext{
18 Wyr. ETPC z 4.05.2006 r., w sprawie nr 17584/04, Celejewski v Polsce.

19 Tak ETPC w wyr. z 9.10.2012 r. w sprawie nr 39502/08 Popenda v. Polska.

20 Wyr. ETPC z 18.9.2012 r. w sprawie nr 31622/07, Dochnal v. Polska; wyr. z 4.10.2005 r., w sprawie nr 29904/02, Górski v Polska).

21 Zob. także wyr. ETPC z 31.5.2011 r. w sprawie nr 24205/06 Krawczak v. Polska.

22 Zob. wyr. z 26.07.2001 r. w sprawie nr 33977/96, Ilijkov v Bułgarii.
} 
Zagrożenie surową karą jako samodzielna podstawa stosowania tymczasowego...

nego rodzaju powiązaniami z krajem, w którym osoba ta została postawiona w stan oskarżenia $^{23}$.

W kontekście podjętej problematyki istotne znaczenie mają nadto rozważania wyrażone przez ETPC w wyroku z 6 lutego 2007 r. w sprawie nr 14348/02, Garycki $v$ Polsce. Organy w tej sprawie, stosując i przedłużając tymczasowe aresztowanie sądowe, nieprzerwanie opierały się na prawdopodobieństwie wysokiej kary, która mogłaby zostać nałożona na skarżącego biorąc pod uwagę poważny charakter przestępstw, które były mu zarzucane. W konsekwencji ETPC stwierdził, że surowość grożącej skarżącemu kary oraz ryzyko ingerowania przez niego w przebieg postępowania nie mogą, same $\mathrm{w}$ sobie lub w powiązaniu $\mathrm{z}$ innymi przesłankami tymczasowego aresztowania, na których opierały się władze sądowe, stanowić ,,istotnej i wystarczającej podstawy" do przetrzymywania skarżącego w areszcie przez długi okres (2 lata i prawie 11 miesięcy).

W świetle przytoczonych orzeczeń, zdziwienie budzi powoływanie się przez Sąd Najwyższy na stanowisko ETPC, wyrażające się uznaniem, iż stosowanie tymczasowego aresztowania wyłącznie z powodu zagrożenia surową karą nie jest sprzeczne z EKPC. Owszem, w orzecznictwie ETPC oraz w literaturze akceptowany jest pogląd, że zagrożenie surową karą może uzasadniać domniemanie, iż oskarżony będzie utrudniał postępowanie w jego początkowej fazie; wraz z upływem czasu i rozwojem postępowania dowodowego argument ten traci jednak na znaczeniu. ETPC dopuszcza stosowanie tej przesłanki, ale pod pewnymi warunkami. Po pierwsze wtedy, gdy znajdzie ona wsparcie w innych dowodach, po drugie, kiedy będzie stosowana na wstępnym etapie postępowania, po trzecie, jeśli nie będzie podstawą uzasadniania długich okresów stosowania tymczasowego aresztowania, i po czwarte, o ile nie będzie uzasadniać stosowania tymczasowego aresztowania w postępowaniu przygotowawczym przez długi czas.

Wydaje się, że podstaw akceptacji uzasadniania stosowania tymczasowego aresztowania zagrożeniem surową karą wyrażonych w orzecznictwie ETPC nie będzie można przełożyć na warunki polskiego sądownictwa, a to dlatego, że w polskich realiach procesowych bywa, iż stosowanie aresztu tymczasowego trwa nawet 4-5 lat i nie stanowi to sytuacji wyjątkowej ${ }^{24}$. Oparcie orzeczenia jedynie o grożącą surową karę i wynikającą z niej obawę „,matactwa” może spowodować swoiste nadużycie, zwłaszcza podczas przedłużania tymczasowego aresztowania już na etapie postępowania sądowego.

Ponadto jak słusznie podnosi TK w uzasadnieniu do cytowanego wcześniej wyroku z 20 listopada 2012 r., w sytuacji, w której sąd pierwszej instancji w pierwszym

\footnotetext{
23 Wyr. ETPC z 4.10.2005 r. w sprawie nr 9190/03, Bacciev v. Mołdawia ; wyr. z 10.11.1969 r., w sprawie nr 1602/62, Stögmüller v Austrii; wyr. z 26.06.1991 r., w sprawie nr 12369/86, Letellier v Francji ; wyr. z 24.08.1998 r., w sprawie nr 27143/95, Contrada v Włochom; wyr. z 24.07.2003 r., w sprawie nr 46133/99, Smirnova v Rosji).

24 Zob. więcej R. Rynkun-Werner, Glosa do uchwały Sądu Najwyższego z dnia 19 stycznia 2012 r., sygn. I KZP 18/11, „Palestra” 2013, nr 11-12.
} 
wyroku skazał oskarżonego na karę nie niższą niż 3 lata pozbawienia wolności, okres trwania tymczasowego aresztowania w postępowaniu toczącym się po wydaniu tego wyroku staje się dla oskarżonego praktycznie nieprzewidywalny i niczym nieograniczony. Przesłanka ta trwa bowiem aż do czasu albo prawomocnego skazania, albo do czasu wykazania w postępowaniu dowodowym, że oskarżony powinien zostać uniewinniony, ewentualnie skazany na karę łagodniejszą. Pamiętać przy tym należy, że postanowienie o przedłużeniu tymczasowego aresztowania wydaje na tym etapie ten sam sąd, który prowadzi postępowanie karne. Brak konieczności wykazania związku pomiędzy grożącą (nieprawomocnie wymierzoną) karą a koniecznością zabezpieczenia prawidłowego toku postępowania powoduje także, że nakaz uzasadnienia, dlaczego niewystarczające byłoby zastosowanie innego nieizolacyjnego środka zapobiegawczego staje się w praktyce iluzoryczny.

Uznać zatem należy, że wykładnia art. 258 § 2 k.p.k. przedstawiona przez SN we wcześniej cytowanej uchwale, według której stanowi on samoistną przesłankę tymczasowego aresztowania koliduje ze standardem konwencyjnym określonym w art. 5 ust. 1 lit c EKPC 25 .

Przechodząc do oceny zmiany art. $258 \S 2$ k.p.k. w kontekście spełnienia wymogów konwencyjnych należy podkreślić, że w uzasadnieniu projektu nowelizacji wskazano, że zmiana art. $258 \S 2$ k.p.k. ma na celu usunięcie nieprawidłowości związanych ze stosowaniem tymczasowego aresztowania na podstawie powyższego przepisu niejako samoczynnie, bez przeprowadzania analizy w zakresie istnienia rzeczywistych przesłanek wskazanych w art. $258 \S 1$ k.p.k.

W związku z tym, w znowelizowanym brzmieniu art. $258 \S 2$ k.p.k. podkreślono, że obawy utrudniania prawidłowego biegu procesu mogą wynikać także z surowości grożącej oskarżonemu kary. Dodanie słowa „także” wskazuje na to, że owe obawy nie mogą wynikać wyłącznie z surowości grożącej kary pozbawienia wolności, lecz powinny one znajdować oparcie w ustaleniach wskazujących na obawy określone w art. 258 § 1 k.p.k. Ponadto, w przepisie nie chodzi tylko o karę wynikającą z ustawowego zagrożenia związanego z czynem zarzucanym lub przypisanym oskarżonemu, określonego w sankcji naruszonego przepisu, ale również tą, wynikającą z mających zastosowanie do niego odpowiednich przepisów części ogólnej kodeksu karnego.

Ponadto, podwyższenie progu w odniesieniu do kary orzeczonej z ,nie niższej niż 3 lata” na „wyższą niż 3 lata”, ma, biorąc pod uwagę całość zmian, ograniczyć stosowanie tymczasowego aresztowania wyłącznie z powodu grożącej oskarżonemu surowej kary ${ }^{26}$.

25 Zob. J. Skorupka, Konstytucyjny i konwencyjny standard stosowania tymczasowego aresztowania, PiP 2007, z. 7, s. 64.

Por. M. Laskowski, Zapobieganie nadużywaniu tymczasowego aresztowania w projekcie nowelizacji kodeksu postępowania karnego, (w:) P. Turek (red.), Przewlekłość tymczasowego aresztowania w Polsce w świetle europejskich standardów ochrony praw człowieka, Warszawa 2013, s. 58. 
Zagrożenie surową karą jako samodzielna podstawa stosowania tymczasowego...

Powyższe rozwiązanie oznacza, że art. $258 \S 2$ k.p.k. w nowym brzmieniu odrzuca interpretację tegoż przepisu wyrażoną przez Sąd Najwyższy w cytowanej wcześniej uchwale, wpisując się tym samym w założenia wypracowane w orzecznictwie ETPC. 


\section{THE THREAT OF SEVERE PUNISHMENT AS A PREMISE FOR THE USE OF REMAND IN CUSTODY IN THE LIGHT OF NATIONAL CASE LAW AND THE EUROPEAN COURT OF HUMAN RIGHTS}

The issue of the correctness of the application of provisional arrest represents the bulk of case law addressed by the European Court of Human Rights (ECHR), which considers each case through the prism of conventional standards. In accordance with article $5 \S 1 \mathrm{c}$ ) Convention for the Protection of Human Rights and Fundamental Freedoms, remand shall apply to ,the lawful arrest or detention of a person effected for the purpose of bringing him before the competent legal authority on reasonable suspicion of having committed an offence or when it is reasonably considered necessary to prevent his committing an offence or fleeing after having done so" Against this background is the issue of threat of severe punishment (article $258 \S 2$ p.p.c.) as an independent rationale for the provisional application of arrest. Important, therefore, is that this provision does not provide for the application of on remand in custody on grounds of threat of severe punishment.

In both ECHR case-law and related literature, the view is accepted that threat of severe punishment may be justified on the presumption that the accused will interfere with the investigation in its early stages. However, with the passage of time and the development of evidence this argument loses ground. ECHR allows use of the premise but only under certain conditions: availability of supporting evidence, the time at which it will be applied during the provisional stage, the length of detention period envisaged, whether the application of provisional arrest can be justified in preparatory proceedings over time.

Hence, recognition by the Supreme Court that the threat of severe punishment is a premise for the provisional application of an arrest warrant is at least questionable, especially in view of the revision of article. $258 \S 2$ p.p.c., and new interpretation of the provision that denies the wording expressed by the Supreme Court in its resolution of 19 January 2012. Therefore, it should be adopted that the interpretation of articles. $258 \S 2$ p.p.c. presented by the Supreme Court in its previously cited resolution, conflicts with the conventional standards referred to in article $5 \S 1 \mathrm{c}$ ) of the ECHR.

Keywords: severe punishment, remand in custody, European Court of Human Rights, human rights 